\title{
Aberrant Splicing of Exon 6 in the Pyruvate Dehydrogenase-E1 $\alpha$ mRNA Linked to a Silent Mutation in a Large Family with Leigh's Encephalomyelopathy
}

\author{
LINDA DE MEIRLEIR, WILLY LISSENS, CHANTAL BENELLI, GERARD PONSOT, \\ ISABELLE DESGUERRE, CÉCILE MARSAC, DIANA RODRIGUEZ, \\ JEAN-MARIE SAUDUBRAY, FLORENCE POGGI, AND INGE LIEBAERS
}

Department of Medical Genetics, Vrije Universiteit, 1090 Brussels, Belgium [L.D.M., W.L., I.L.]; Inserm U30, Hôpital Necker, 75015 Paris, France [C.B.]; Department of Neuropediatrics, Hôpital Saint Vincent de Paul, 75014 Paris, France [G.P., I.D., D.R.]; Inserm U75, Faculté Necker, 75015 Paris, France [C.M.]; Department of Metabolics, Hopital Necker, 75015 Paris, France [J.-M.S., F.P.] \begin{abstract}
ABST
Pyruvate dehydrogenase (PDH)-E1 $\alpha$ deficiency has re-
cently been studied at the molecular-genetic level. The gene is situated on the $\mathrm{X}$ chromosome. We report on an unusual mutation in a familial $\mathrm{E} 1 \alpha$ deficiency. In fibroblasts, PDH deficiency was diagnosed in a young infant presenting with Leigh's encephalomyelopathy and in a maternal nephew with episodes of "malaises." In the two affected children as well as their mothers we found a silent mutation in exon 6 of the PDH-E1 $\alpha$ and an aberrant splic-
\end{abstract}

ing of exon 6 in some of the cDNA clones. This case emphasizes the need for both genomic and CDNA analysis in cases where a PDH-E1 $\alpha$ deficiency is strongly suspected. (Pediatr Res 36: 707-712, 1994)

PDH, pyruvate dehydrogenase

\section{Abbreviations}

PDHC, pyruvate dehydrogenase complex

PCR, polymerase chain reaction
The PDHC is responsible for the irreversible conversion of pyruvate to acetyl-CoA. PDHC is a multienzyme complex consisting of multiple copies of three catalytic subunits [pyruvate decarboxylase (E1), dihydrolipoamide acetyltransferase (E2), and dihydrolipoamide dehydrogenase (E3)] and two regulatory subunits (E1 kinase and phospho-E1 phosphatase). Pyruvate decarboxylase, $E 1$, has two subunits ( $\alpha$ and $\beta$ ). An abnormal E1 $\alpha$ subunit of the PDHC is the cause of E1 enzyme deficiency in a number of cases $(1,2)$. The E1 $\alpha$ cDNA (3-6) and the genomic DNA (7) have been cloned and sequenced. The gene consists of 11 exons and is located on the X chromosome at Xp 22.1-p 22.2 (8). The clinical presentation of a PDH-E1 $\alpha$ deficiency is variable and may include severe neonatal lactic acidosis, Leigh's encephalomyelopathy, mental retardation with cerebral developmental abnormalities, or intermittent ataxia. Recently, a number of investigators characterized mutations in the PDH-

Received December 6, 1993; accepted July 5, 1994.

Correspondence and reprint requests: L. De Meirleir, AZK-VUB Department of Pediatrics, Laarbeeklaan 101, 1090 Brussels, Belgium.

Supported by the Belgian FGWO Grant 3.0065.87.
E1 $\alpha$ gene believed to be responsibie tor the enzyme deficiency (9).

We have analyzed a family in which several male members had similar clinical symptoms associated with a biochemical deficiency of PDHC. The mode of inheritance in this family suggests an X-linked disease. Genomic DNA as well as cDNA of some of the affected individuals was analyzed and sequenced to define the mutation responsible for the PDH-E $1 \alpha$ deficiency in this family.

\section{METHODS}

\section{Patients}

Index case. G.D. (C, Fig. 1) is the first son of nonconsanguineous parents. His mother had several miscarriages. She also had two brothers, who died in childhood. The oldest one $(A$, Fig. 1$)$ died when he was 23 mo old after a febrile illness. He had an important psychomotor retardation with seizures. No additional investigations were performed. The other brother $(B$, Fig. 1$)$ presented with irregular respiration and apnea at $4 \mathrm{mo}$. At $8 \mathrm{mo}$, he 


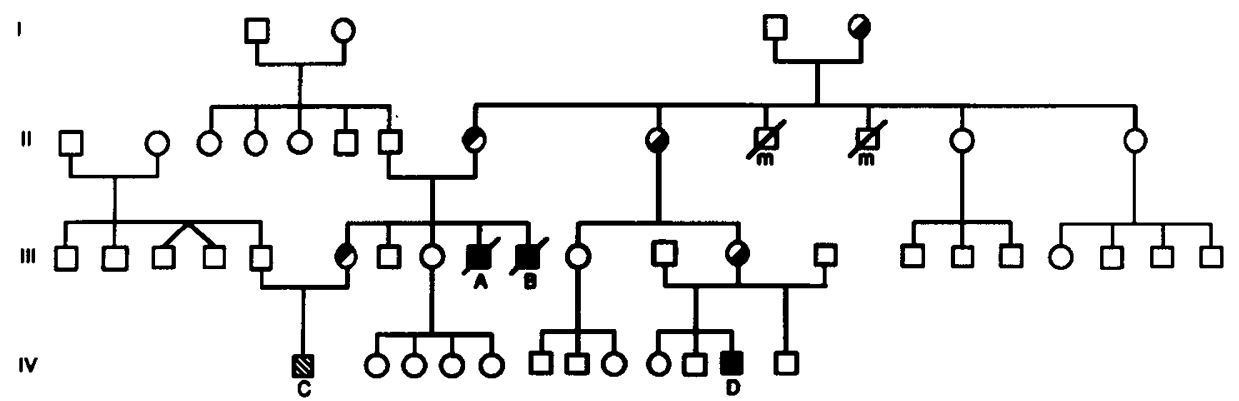

Figure 1. Pedigree of the family with Leigh's encephalomyelopathy. Open symbols indicate the healthy family members, hatched symbols the affected ones. Semiopen symbols indicate the female healthy carriers. A slash in the symbol indicates deceased individuals. $m$, died of meningitis.

had developed a moderate motor delay and bilateral ocular ptosis. At the age of $2 \mathrm{y}$, ataxia, pyramidal tract signs, and vertical ophthalmoplegia were observed. He was investigated at the age of $4 \mathrm{y}$, and increased postprandial lactate and pyruvate levels were found. A clinical diagnosis of Leigh's encephalomyelopathy was made, and a PDH deficiency was suspected. Further enzymologic studies could not be performed. He died at the age of $5.5 \mathrm{y}$ as a consequence of a respiratory arrest.

G.D. presented with respiratory difficulties at the age of 2.5 mo. A metabolic acidosis with increased serum lactate and pyruvate was found. Episodic deep respiration associated with sudden eye movements appeared and became more frequent. A diagnosis of Leigh's encephalomyelopathy was suspected at the age of $11 \mathrm{mo}$. PDH deficiency was found (Table 1). He was treated with dichloropropionate, which resulted in a decrease of serum lactate and pyruvate. At the age of $2 y$, a moderate developmental delay and mild ataxia had developed. An episode of cardiorespiratory arrest occurred during a pulmonary infection at the age of $2.5 \mathrm{y}$, leaving cortical blindness as a sequela.

Case 2. T.D. (D, Fig. 1), the son of a niece of G.D.'s mother, was admitted to the hospital at 3 mo of age for episodes of postprandial hypertonia with dyspnea attrib-

Table 1. Pyruvate dehydrogenase activity in lymphocytes and in muscle

\begin{tabular}{lcc}
\hline & $\mathrm{nmol} / \mathrm{min} / \mathrm{mg}$ & $\begin{array}{c}\text { \% of normal } \\
\text { activity }\end{array}$ \\
\hline PDH activity & & \\
Index patient (G.D.) & & 32 \\
$\quad$ Lymphocytes & 0.239 & 21 \\
$\quad$ Muscle (mitochondria) & 1.244 & 50 \\
Case 2 (T.D.): lymphocytes & 0.373 & \\
Controls & & \\
$\quad$ Lymphocytes & $0.747 \pm 0.029(n=25)$ & \\
$\quad$ Muscle (mitochondria) & $5.830 \pm 0.330(n=12)$ & \\
PDH activity in fibroblasts & & 16 \\
Index patient (G.D.) & $0.62 / 0.64^{*}$ & \\
Patient 2 (T.D.) & $0.14 / 0.22$ & \\
Mother of G.D. & $1.48 / 1.50$ & \\
Controls & & \\
$\quad$ Range & $1.01-2.31 / 1.10-2.61$ & \\
Mean (n=4) & $1.32 / 1.54$ & \\
\hline
\end{tabular}

${ }^{*}$ Native/dichloracetate activated. uted to a gastroesophageal reflux. Fasting lactate and pyruvate levels were normal, but increased abnormally after feeding. Because a PDH deficiency had been diagnosed in another member of the family (G.D.), the PDH activity was measured and found to be deficient in the patient's lymphoblasts and fibroblasts (Table 1).

\section{General}

All enzymes used in this study were from Amersham (Buckinghamshire, UK), except for the Taq DNA polymerase (Perkin Elmer Cetus) and BslI (New England Biolabs). For cDNA synthesis, the cDNA synthesis kit from Pharmacia (Piscataway, NJ) was used. Sequencing was performed using Sequenase version 2.0 (United States Biochemical Corp., Cleveland, OH). For the sequencing of the cDNA clones, the strategy of De Meirleir et al. (4) was used.

All oligonucleotides were synthesized on a model 391 Applied Biosystems (Foster City, CA) DNA synthesizer.

\section{Enzyme Studies}

Cell preparation. Peripheral mononuclear cells from heparinized blood were separated at room temperature on a Ficoll-Paque gradient (10) and treated as previously described (11) before the PDH assay was performed. Fibroblasts were cultured and further processed by the method of Sheu et al. (12).

Muscle mitochondrial preparation. An open biopsy of the quadriceps femoris $(0.7 \mathrm{~g})$ of patient G.D. was performed under local anesthesia with the written consent of the parents. Mitochondria were isolated according to the methods of Morgan-Hughes et al. (13).

Polarographic studies on purified mitochondria. The freshly isolated mitochondria were incubated with different substrates as previously described (14).

PDH assay. PDH activity was assayed as the release of ${ }^{14} \mathrm{CO}_{2}$ from ${ }^{14} \mathrm{C}$-pyruvate. Mitochondrial proteins $(10 \mu \mathrm{g})$ or a cell extract (obtained from $10^{6}$ cells) was preincubated in a mixture containing $0.5 \mathrm{mM} \mathrm{CaCl} \mathrm{Ca}_{2}$ and $10 \mathrm{mM}$ $\mathrm{MgCl}_{2}$ for $10 \mathrm{~min}$ at $37^{\circ} \mathrm{C}$. The lymphocyte PDH assay was initiated as described by Clot et al. (11). The fibroblast PDH assay was performed according to the methods of Sheu et al. (12). Respiratory chain enzymes on 
isolated muscle mitochondria were measured according to the methods of Morgan-Hughes et al. (13).

\section{Molecular Studies}

RNA preparation and $\boldsymbol{c D N A}$ synthesis. Total RNA was prepared from cultured fibroblasts as previously described (15). Polyadenylated RNA was then selected on Dynabeads Oligo (dT) ${ }_{25}$ (Dynal, Oslo, Norway) from 80 $\mu \mathrm{g}$ of total RNA according to the instructions of the manufacturer, and the resulting product was used for cDNA synthesis. After synthesis of the second cDNA strand, the total volume was brought to $200 \mu \mathrm{L}$ by the addition of Tris/EDTA $(\mathrm{pH} 8)$ and extracted twice with Tris/EDTA-saturated phenol and chloroform/isoamyl alcohol (ratio 24:1).

PCR of E1 $\alpha$ cDNA and cloning. One $\mu \mathrm{L}$ of the purified cDNA reaction mixture was used in a standard $100-\mu \mathrm{L}$ PCR reaction (16) in a Perkin Elmer Cetus DNA Thermal Cycler programmed for $5.0 \mathrm{~min}$ of denaturation at $94^{\circ} \mathrm{C}$, followed by 30 cycles of $1.0 \mathrm{~min}$ of denaturation at $94^{\circ} \mathrm{C}$, $1.0 \mathrm{~min}$ of annealing at $60^{\circ} \mathrm{C}$, and $3.0 \mathrm{~min}$ of extension at $72^{\circ} \mathrm{C}$, and a final extension period of $7.0 \mathrm{~min}$ at $72^{\circ} \mathrm{C}$.

The oligonucleotide primer sequences were $5^{\prime}$-CCTCCTGGGTTGTGAGGAGTCGACGCTGCC-3' (PDH100) and 5'-GTTGAGAACACTGTCTGGTACCCCCCTGAAGG-3' (PDH101). These primers enclose the complete coding sequence of the E1 $\alpha$ cDNA and correspond to nucleotide positions 59 to 88 (PDH100) and 1333 to 1302 (PDH101) (4, 9).

A C to A substitution was deliberately introduced in PDH100 at position 81 and a $\mathrm{G}$ to $\mathrm{C}$ substitution at position 1313 in PDH101 such that unique AccI and KpnI restriction sites would be incorporated into the PCR product (1274 bp).

After PCR, the amplified fragment was purified on Centricon 100 (Amicon, Danvers, MA), restricted with $A c c \mathrm{I}$ and KpnI, and ligated in $A c c \mathrm{I} / K p n \mathrm{I}$-digested plasmid vector pUC18. After transformation in Escherichia coli strain JM109, colonies with inserts were selected for further analysis.

For the PCR amplification of a fragment surrounding exon 6 , the same cDNA libraries were used with primers PDH50 (5'-CTTTCCGTCCGAGAAATTCTCG-3'; positions 490-511) and PDH51 (5'-AGGGTCACTCATACTGTGTCCG-3'; positions 996-975).

PCR conditions were 30 cycles of $1.0 \mathrm{~min}$ at $94^{\circ} \mathrm{C}, 1.0$ min at $55^{\circ} \mathrm{C}$, and $1.5 \mathrm{~min}$ at $72^{\circ} \mathrm{C}$ and a final extension of $7.0 \mathrm{~min}$ at $72^{\circ} \mathrm{C}$.

Genomic amplification of exon 6 and flanking sequences. Exon 6 and flanking intronic sequences were PCR amplified by using primers PDH37 (5'-AGTATCTCCCCTCATGGATTTC-3'; 54-33 bp in front of exon 6 in intron 5) and PDH38 (5'-TGCTACTTCTTTAG AAATTCAA-3'; $83-62$ bp after exon 6 in intron 6 ). The same PCR conditions as used for primers PDH50/PDH51 were used with $1 \mu \mathrm{g}$ of genomic DNA.
After purification of the amplified fragment (230 bp) on Centricon 100, it was blunt-end cloned in the SmaI site of pUC18. For the detection of the A to G substitution at the third position of codon 185 in exon 6 , a PCR using primers PDHG (5'-GATTGCTCTAGCCTGTACCTATAA-3'; cDNA positions 633-656) and PDH38 was used. The substitution of $\mathrm{AG}$ by $\mathrm{CC}$ in PDHG (bold) creates a unique $B s l$ I site in the PCR fragment (159 bp) when the $A$ to $G$ substitution at codon 185 is present.

\section{RESULTS}

PDH enzyme assays. PDH activities were decreased in the two patients who were studied. The index patient, G.D., had 45\% residual PDH activity in his fibroblasts, whereas patient T.D. had only $15 \%$ residual activity. Residual activities were higher in the lymphocytes $(50 \%$ activity) of patient T.D. compared with the fibroblast values (Table 1). The mother of patient G.D. had normal PDH activity.

Oxidation of substrates by intact mitochondria. Freshly isolated muscle mitochondria were incubated with different substrates, and oxygen uptake was measured in the presence and after consumption of ADP (Table 2). The muscle mitochondria of patient G.D. actively oxidized glutamate and succinate and showed normal respiratory control ratios with these substrates. The respiratory control ratio with pyruvate was very low, because the mitochondria were unable to oxidize pyruvate. Normal values were recovered when glutamate was added.

Respiratory chain enzymatic assays. Normal values were found in the muscle of patient G.D. for cytochrome $c$ oxidase, succinate cytochrome $c$ reductase, and citrate synthase (data not shown).

Molecular studies. After PCR amplification of the PDHE1 $\alpha$ gene of the index patient (G.D.) and cloning in pUC18, two types of clones were obtained, differing in length by about $100 \mathrm{bp}$. Four clones of each type were mixed two by two and completely sequenced. The larger clones represented the normal PDH-E1 $\alpha$ sequence, except for an $\mathrm{A}$ to $\mathrm{G}$ substitution in the third position of codon 185 (nucleotide position 660) in exon 6 (Fig. $2 A$ ). The glycine at this position (GGA) is not changed by the substitution (GGG). The shorter clones missed the com-

Table 2. Oxygen consumption in muscle mitochondria from patient G.D. and 10 controls*

\begin{tabular}{|c|c|c|c|c|}
\hline & \multicolumn{2}{|c|}{$\begin{array}{c}\text { Oxygen } \\
\text { consumption }\end{array}$} & \multicolumn{2}{|c|}{$\mathrm{RCR}$} \\
\hline & $\begin{array}{l}\text { Patient } \\
\text { G.D. }\end{array}$ & $\begin{array}{l}\text { Controls } \\
(n=10)\end{array}$ & $\begin{array}{l}\text { Patient } \\
\text { G.D. }\end{array}$ & $\begin{array}{l}\text { Controls } \\
(n=10)\end{array}$ \\
\hline Malate + pyruvate & 68 & $169 \pm 59$ & 4.0 & $5.0 \pm 2.4$ \\
\hline Malate + glutamate & 117 & $114 \pm 39$ & 8.0 & $5.9 \pm 2.4$ \\
\hline Rotenone + succinate & 118 & $180 \pm 52$ & 1.7 & $2.0 \pm 0.7$ \\
\hline
\end{tabular}

*Oxygen consumption, measured at $25^{\circ} \mathrm{C}$ in the presence of ADP (state 3), is expressed in ng atoms oxygen $/ \mathrm{min} / \mathrm{mg}$ mitochondrial proteins. RCR, respiratory control ratio- the ADP-stimulated respiration rate (state 3 ) divided by the respiration rate after transformation of ADP into ATP (state 4). 


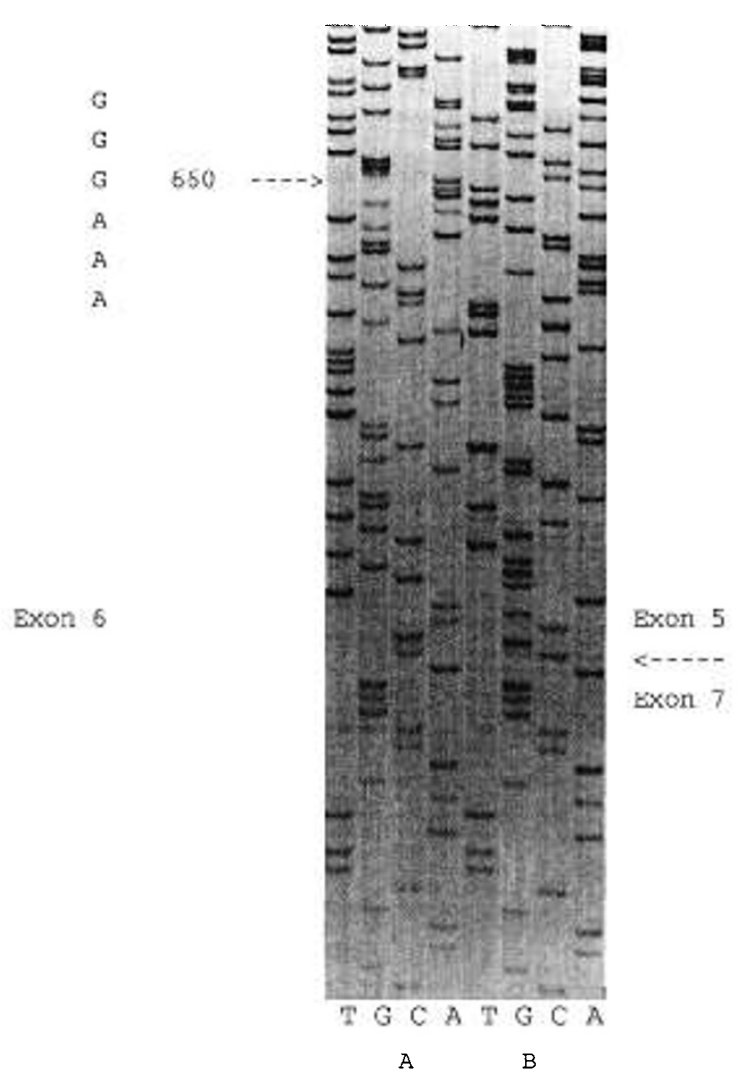

Figure 2. $A$, Sequence analysis of the larger clone reveals an $\mathrm{A}$ to $\mathrm{G}$ substitution at nucleotide position $660 . B$, Sequence analysis of the exon 6 deleted clone; exon 7/exon 5 boundary is indicated.

plete exon 6 (31 amino acids, position 171-201), shortening the complete cDNA with 93 bp (Fig. 2B).

Sequence analysis of exon 6 and boundaries (including splice donor and acceptor sites), amplified from genomic fibroblast DNA, revealed a normal sequence of $31 \mathrm{bp}$ of intron 5 and 61 bp of intron 6 . In exon 6 , the only change was the $A$ to $G$ substitution already found in the cDNA (data not shown). For the easy detection of this mutation in genomic DNA, we have designed a modified primer (PDHG) such that upon PCR amplification with this primer and $\mathrm{PDH} 38$ a unique $B s l \mathrm{I}$ site is introduced in the sequence in the presence of the mutation.

The mutation was found in a hemizygous form in the two patients and in a heterozygous form in the mothers, both in genomic DNA from fibroblasts and leukocytes, except for the mother of patient T.D., from whom only leukocytes were available (Fig. 3). It was found neither in the genomic leukocyte DNA of 20 normal males and 10 females nor in 23 cDNA libraries from normal (five female and four male) and PDH-deficient (six male and eight female) patients as evaluated by sequencing.

To get an idea of the proportion of normal length versus exon 6-deleted mRNA, the cDNA libraries of the two patients and the mother of patient 1 were used for amplification of part of the cDNA, including exon 6 (primers PDH50 and PDH51). Representative results are shown in Figure 4. In 10 unrelated cDNA from five normal and five $\mathrm{PDH}$-deficient females, no evidence for splicing out of

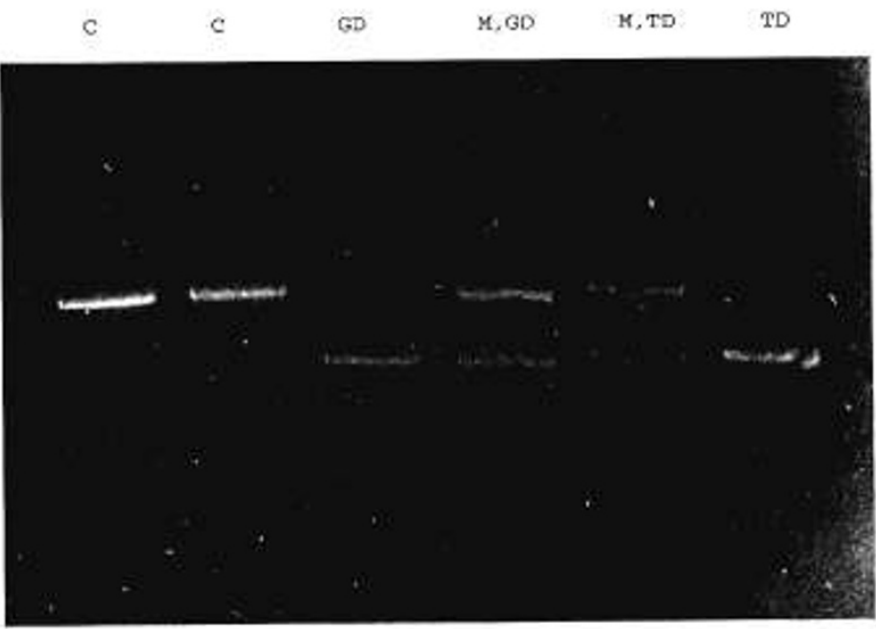

Figure 3. Digestion of leukocyte DNA with $B s l$. Normal controls $(C)$ are uncut. The DNA of the two patients ( $G D$ and $T D$ ) are completely digested, whereas those of their mothers $(M, G D$ and $M, T D)$ are heterozygous.

exon 6 was found. In contrast, both patients had approximately $50-80 \%$ of messengers with exon 6 spliced out. By selecting the exon 6-containing cDNA of the mother, using primers PDHG (in exon 6) and PDH51 in a PCR reaction and digestion with $B s l \mathrm{I}$, it could be demonstrated that approximately $90 \%$ of the cDNA did not contain the $A$ to $\mathrm{G}$ mutation, confirming the nonrandom expression of the E1 $\alpha$ gene (17). As expected, all exon 6-containing cDNA from both patients were fully digested with $B s l$, whereas in controls no digestion was observed.

\section{DISCUSSION}

In the literature, fewer than 30 cases of PDH-E1 $\alpha$ deficiency with mutations in the $\mathrm{E} 1 \alpha$ gene have been reported $(9,17-26)$. Most cases are due to new or germline mutations.

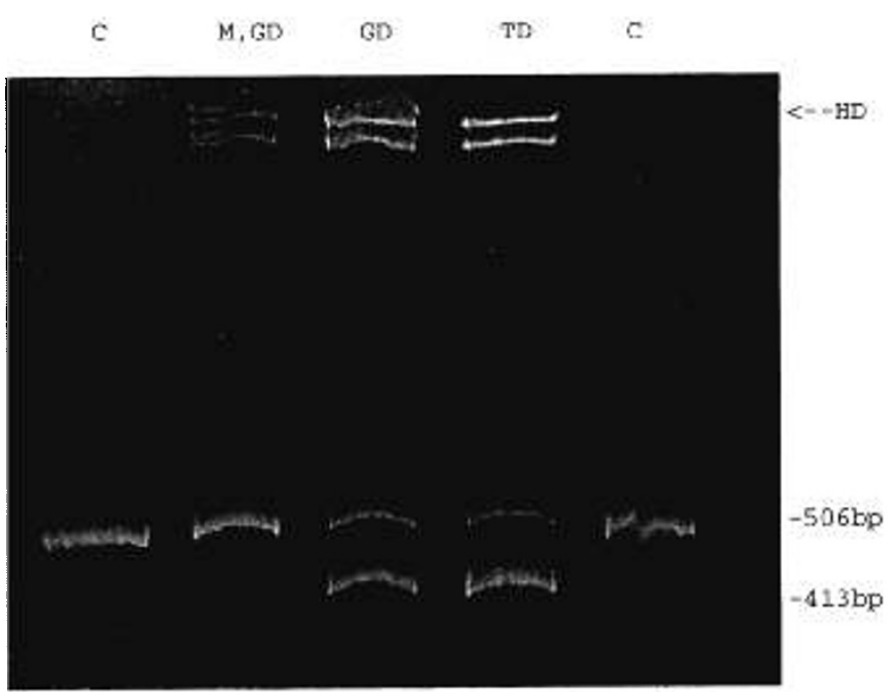

Figure 4. Estimation of the proportion of normal length $v s$ exon 6-deleted cDNA. $H D$, heteroduplexes formed during PCR between the 506-bp and 413-bp fragments. See Figure 3 for explanation of other abbreviations. 
PDH-E1 $\alpha$ deficiency can have several clinical presentations. One of these is Leigh's encephalomyelopathy. Because the E1 $\alpha$ gene is located on the $\mathrm{X}$ chromosome, one would expect this to be an X-linked recessive disease, with asymptomatic female carriers. However, previous studies (17) have shown that girls also can be severely affected, with early onset presentations and cerebral developmental abnormalities. A mother with mental retardation and a daughter with severe brain anomalies and the same point mutation in the PDH-E1 $\alpha$ gene were described by Dahl et al. (18).

We have investigated a family with Leigh's encephalomyelopathy affecting several males. A biochemical E1 deficiency was found in the tissues of two affected individuals, and a silent mutation was found in exon 6 of their $\mathrm{PDH}-\mathrm{E} 1 \alpha$ gene. Study of the expression of the E1 $\alpha$ gene demonstrated that a partial splicing out $(50-80 \%)$ of the entire exon 6 was associated with this mutation. The same silent mutation was present in heterozygous form in the genomic DNA of the mothers of these patients. In the family discussed here, the disease seems to be expressed in boys only. The mothers, although biochemically and clinically normal, carry the same mutation as their affected sons.

Particular observations were made about the expression of the $E 1 \alpha$ genes in the mother of the index patient, G.D.: the silent mutation in exon 6 was found in a minority of her cDNA and also splicing out of this exon was minor. However, in contrast to the patients, most of her cDNA had undergone normal splicing.

This demonstrates that in the mother the $\mathrm{X}$ chromosome carrying the mutated E1 $\alpha$ allele is preferentially inactivated (nonexpressed), whereas in most cells the wild-type allele is expressed. This nonrandom $\mathrm{X}$ inactivation could explain the asymptomatic phenotype of the females in this family. This study therefore is in agreement with previous studies in which it was shown that the degree of clinical penetration of the disease in PDH-E1 $\alpha-$ deficient females correlates with the proportional inactivation of the mutated X chromosome (17-19).

Exon 6 contains part of the well-conserved thiamine pyrophosphate binding site (27), which is of regulatory importance for the PDHC. Splicing out of this exon results in a predicted protein in which this functional site is absent and thus deficient. The carboxyterminal end remains unchanged, because the deletion does not cause a frame shift.

Aberrant splicing is usually caused by mutations in splice donor or acceptor sites. This is not the case in the family studied. It is tempting to speculate that the silent mutation in the middle of exon 6 is functionally associated with the aberrant splicing of this exon. To our knowledge, only one such event has been suggested to occur due to a silent mutation in exon 8 of the human $\mathrm{X}$-linked hypoxanthine-guanine phosphoribosyltransferase (hprt) gene (28). Deficiency of the enzyme results in a severe neurologic disorder with automutilation (Lesh-Nyhan disease). In this particular case, a silent exonic TTC to TTT change resulted in $90 \%$ of the mRNA having undergone an aberrant splicing out of the mutated exon 8. An explanation of this event was found in terms of a hypothetical stem-loop structure necessary for exposure of the splice sites. This secondary structure was partially disrupted by the mutation, resulting in abnormal splicing. In exon 6 of the E1 $\alpha$ gene, several potential stem-loop structures can be found starting with bases 629-632 (CTGG) and ending with bases 708-705 (GACC), which are also the end of exon 6 . In one configuration, a hypothetical stretch of five A-T interstrand bonds interrupted by two nonpairing bases can be drawn (656ATGGAAA-662 and 681-TTTATAT-687), and in total 15 interstrand bonds can be supposed. The A to $\mathrm{G}$ substitution at base position 660 (underline) would then destroy this structure. However, direct evidence for such a hypothetical secondary structure is not available, and this explanation remains tentative. The notion that the silent mutation is a simple polymorphism accidentally associated with the aberrant splicing event of exon 6 cannot be ruled out, although it has not been mentioned in the literature and we have not found it in $80 \mathrm{X}$ chromosomes from both normal and PDH-deficient patients.

Alternatively spliced mRNA events have been occasionally described as splice mutations in tumor cells. In these tumor cell lines, aberrant splicing of an exon has been reported with single base substitutions resulting in a stop codon. Fukuda and Ogawa (29) found a partial exon 8 skipping in the p53 gene of a rat hepatoma cell line, associated with a single base substitution $G$ to $T$, resulting in a stop codon in exon 8 .

Exon skipping has also been documented in the retinoblastoma gene (30), where single base changes in the exon, but adjacent to an AG or GT splice signal, lead to a new stop codon.

Interestingly, the normal PDH-E1 $\alpha$ cDNA of Koike $e t$ al. (5) derived from human fetal liver tissue also misses exon 6. Because the corresponding genomic DNA was not sequenced, the reason for this remains unexplained.

In conclusion, we describe a family in which several male members were affected with Leigh's encephalomyelopathy due to a PDH-E1 deficiency. A splicing out of exon 6 was associated with a silent mutation within exon 6 .

\section{REFERENCES}

1. McKay N, Petrova-Benedict R, Thoene J, Bergen B, Wilson W, Robinson BH 1986 Lactic acidaemia due to pyruvate dehydrogenase deficiency, with evidence of protein polymorphism in the $\alpha$-subunit of the enzyme. Eur J Pediatr 144:445-450

2. Brown GK 1992 Pyruvate dehydrogenase E1 $\alpha$ deficiency. J Inherit Metab Dis $15: 625-633$

3. Dahl H-HM, Hunt SM, Hutchison WM, Brown GK 1987 The human pyruvate dehydrogenase complex. J Biol Chem 262:7398-7403

4. De Meirleir LJ, MacKay N, Lam AM, Robinson BH 1988 Isolation of a fulllength complementary DNA coding for human E1 $\alpha$ subunit of the pyruvate dehydrogenase complex. J Biol Chem 263:1991-1995

5. Koike K, Ohta S, Urata Y, Kagawa Y, Koike M 1988 Cloning and sequencing of cDNAs encoding $\alpha$ and $\beta$ subunits of human pyruvate dehydrogenase. Proc Natl Acad Sci USA 85:41-45

6. Ho L, Wexler ID, Liu T-C, Thekkumkara TJ, Patel MS 1989 Characterization of cDNAs encoding human pyruvate dehydrogenase $\alpha$ subunit. Proc Natl Acad Sci USA 86:5330-5334 
7. Maragos C, Hutchison WM, Hayasaka K, Brown GK, Dahl H-HM 1989 Structural organization of the gene for the El $\alpha$ subunit of the human pyruvate dehydrogenase complex. J Biol Chem 264:12294-12298

8. Brown RM, Dahl H-HM, Brown GK 1989 X-chromosome location of the functional gene for the E1 alpha subunit of the pyruvate dehydrogenase complex. Genomics 4:174-181

9. Dahl H-HM, Brown GK, Brown RM, Hansen LL, Kerr DS, Wexler ID, Patel MS, De Meirleir L, Lissens W, Chun K, MacKay N, Robinson BH 1992 Mutations and polymorphisms in the pyruvate dehydrogenase E1 $\alpha$ gene. Human Mutation 1:97-102

10. Boyum A 1968 Isolation of mononuclear cells and granulocytes from human blood. J Clin Lab Invest 97:77-89

11. Clot JP, Benelli C, Fouque F, Bernard R, Durand D, Postel-Vinay MC 1992 Pyruvate dehydrogenase activity is stimulated by growth hormone in human mononuclear cells: a new tool to measure GH responsiveness in man. J Clin Endocrinol Metab 74:1258-1262

12. Sheu K-FR, Hu C-WC, Utter MF 1981 Pyruvate dehydrogenase complex activity in normal and deficient fibroblasts. J Clin Invest 67:1463-1471

13. Morgan-Hughes JA, Darveniza P, Khan SN, Landon DN, Sherrat RM, Land JM, Clark JB 1977 A mitochondrial myopathy characterized by a reducible cytochrome b. Brain 100:617-640

14. Degoul F, Nelson I, Lestienne P, Francois D, Romero N, Duboc D, Eymard B, Fardeau M, Ponsot G, Paturneau-Jouas M, Chaussain M, Leroux JP, Marsac C 1991 Deletions of mitochondrial DNA in Kearns-Sayre and ocular myopathies: genetic, biochemical and morphological studies. J Neurol Sci 101:168-177

15. Chomczynski $P$, Sacchi $N 1987$ Single-step method of RNA isolation by acid guanidinium thiocyanate-phenol-chloroform extraction. Anal Biochem 162:156-159

16. Saiki R, Gelfand D, Stoffel S, Scharf S, Higuchi R, Horn G, Mullis K, Erlich H 1988 Primer-directed enzymatic amplification of DNA with a thermostable DNA polymerase. Science 239:487-491

17. De Meirleir L, Lissens W, Denis R, Wayenberg JL, Michotte A, Brucher JM, Vamos E, Gerlo E, Liebaers I 1993 Pyruvate dehydrogenase deficiency: clinical and biochemical diagnosis. Pediatr Neurol 9:216-220

18. Dahl H-HM, Hansen LL, Brown RM, Danks DM, Rogers JG, Brown GK 1992 X-linked pyruvate dehydrogenase E1 $\alpha$ subunit deficiency in heterozygous females: variable manifestation of the same mutation. J Inherit Metab Dis 15:835 -847
19. Dahl H-HM, Maragos C, Brown RM, Hansen LL, Brown GK 1990 Pyruvate dehydrogenase deficiency caused by deletion of a 7-bp repeat sequence in the E1 $\alpha$ gene. Am J Hum Genet 47:286-293

20. Chun K, MacKay N, Petrova-Benedict R, Robinson BH 1993 Mutations in the X-linked E1 $\alpha$ subunit of pyruvate dehydrogenase leading to deficiency of the pyruvate dehydrogenase complex. Hum Molec Genet 2:449-454

21. De Meirleir L, Lissens W, Vamos E, Liebaers I 1992 Pyruvate dehydrogenase $(\mathrm{PDH})$ deficiency caused by a 21-base pair insertion mutation in the E1 $\alpha$ subunit. Hum Genet 88:649-652

22. Matthews PM, Marchington DR, Squier M, Land J, Brown RM, Brown GK 1993 Molecular genetic characterization of an X-linked form of Leigh's syndrome. Ann Neurol 33:652-655

23. Takakubo F, Thornburn DR, Dahl H-HM 1993 A four-nucleotide insertion hotspot in the X-chromosome located pyruvate dehydrogenase $\mathrm{E} 1 \alpha$ gene (PDHA1). Hum Molec Genet 2:473-474

24. Takakubo F, Thornburn DR, Dahl H-HM 1993 A novel mutation and a polymorphism in the X-chromosome located pyruvate dehydrogenase E1 $\alpha$ gene (PDHA1). Hum Molec Genet 2:1961-1962

25. Wexler ID, Hemalatha SG, Liu T-C, Berry SA, Kerr DS, Patel MS 1992 A mutation in the $\alpha$ subunit of pyruvate dehydrogenase associated with variable expression of pyruvate dehydrogenase complex deficiency. Pediatr Res 32:169-174

26. Hansen LL, Brown GK, Brown RM, Dahl H-HM 1993 Pyruvate dehydrogenase deficiency caused by a 5 base pair duplication in the E1 $\alpha$ subunit. Hum Molec Genet 2:805-807

27. Hawkins CF, Borges A, Perham RN 1989 A common structural motif in thiamine pyrophosphate-binding enzymes. FEBS Lett 255:77-82

28. Steingrimmsdottir H, Rowlmey G, Dorado G, Cole J, Lehman AR 1992 Mutations which alter splicing in the human hypoxanthine-guanine phosphoribosyltransferase gene. Nucleic Acids Res 20:1201-1208

29. Fukuda I, Ogawa K 1992 Alternatively-spliced p 53 mRNA in the FAA-HTC1 rat hepatoma cell line without the splice site mutations. Cell Struct Funct $17: 427-432$

30. Yandell DW, Campbell TA, Dayton SH, Petersen R, Walton D, Little JB, McConkie-Rosell A, Buckley EG, Dryja TD 1989 Oncogenic point mutations in the human retinoblastoma gene: their application to genetic counseling. $N$ Engl J Med 321:1689-1695 